\title{
Comparison of the Effect of Training on How to Use Electroshock by Demonstration in Ambulance and Simulation Methods on Knowledge and Skill of Nursing Students of Aja University of Medical Sciences
}

\author{
Arabpoor. AR ${ }^{1}$ \\ ${ }^{*}$ Farsi. $Z^{2}$ \\ Habibi. $\mathrm{H}^{3}$ \\ 1- MSc Student of Military Nursing, \\ Military Nursing Department, \\ Faculty of Nursing, Aja \\ University of Medical Sciences, \\ Tehran, Iran. \\ 2- ( ${ }^{\star}$ Corresponding Author) \\ Ph.D., Medical-Surgical Nursing, \\ Associate Professor, Research \\ Department and Community \\ Health, Faculty of Nursing, Aja \\ University of Medical Sciences, \\ Tehran, Iran. \\ Email: zahrafarsi@gmail.com \\ z.farsi@ajaums.ac.ir \\ 3- MSc in Nursing, Instructor, \\ Pediatric Department, Faculty \\ of Nursing, Aja University of \\ Medical Sciences, Tehran, Iran.
}

\begin{abstract}
Introduction: Cardiovascular disorders are the first cause of global mortality. Health care providers can save the lives of millions of people by providing timely and appropriate health care and preventing many disabilities. Therefore, it is necessary to use the best education methods to enhance the knowledge and skills of individuals.

Objective: This study aimed to determine the effectiveness of training on the accurate use of electroshock using demonstration and simulation methods in ambulance and to increase the knowledge and skill of nursing students of Ajay University of Medical Sciences.
\end{abstract}

Material and Methods: This randomized clinical trial was conducted in 2019. A total of 45 students of Aja Nursing Faculty, Tehran, Iran were recruited by purposive sampling method and randomly divided into two experimental and one control group. The intervention included educating in the clinical skills lab by simulation method and in an ambulance through demonstration. A researcher-made tool including a knowledge questionnaire and a checklist was used to assess how to use electroshock in pre-test and post-test with two weeks intervals.

Results: The mean score of knowledge and skills in the pre-intervention phase was not significantly different in the three groups $(\mathrm{P}<0.05)$, but this difference was significant after the intervention $(\mathrm{P}<0.05)$. However, the scores in both the simulation and demonstration groups were higher than that in the control group. Moreover, students' knowledge and skill scores in the post-test phase increased in three groups $(\mathrm{P}<0.05)$.

Discussion and Conclusion: Educating correct use of electroshock through simulation and demonstration in a real environment enhances the knowledge and skills of nursing students. Further studies with larger samples size and in other health care groups are recommended.

Keywords: Cardiopulmonary Resuscitation, Demonstration, Education, Nursing, Simulation, Student. 


\title{
مقايسه تأثير آموزش نحوهى صحيح بكاركيرى دستَاه الكتروشوك به روش نمايش عملى در

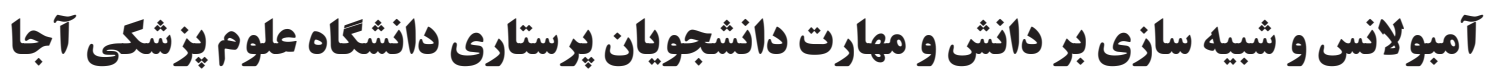

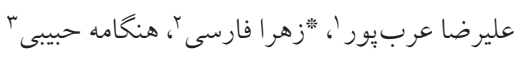

جكيده

مقدمه: مشكلات قلبى عروقى به عنوان اولين عامل مرك و مير جهانى مىباشند كه با ارائه خدمات درمانى به موقع و

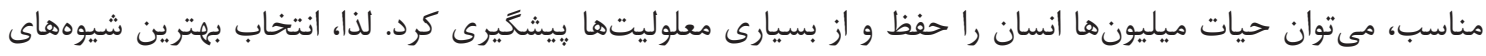

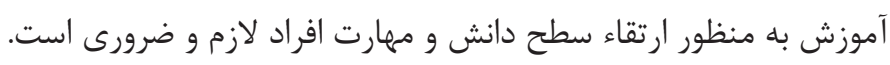

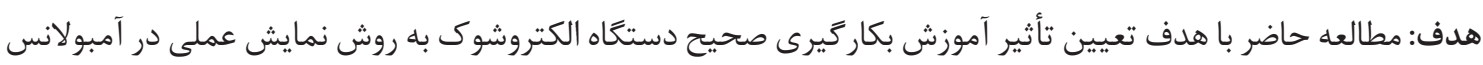

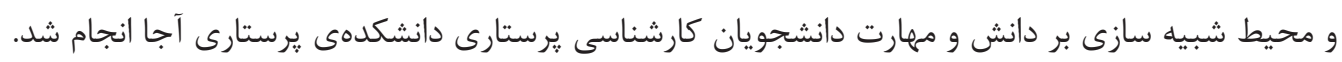

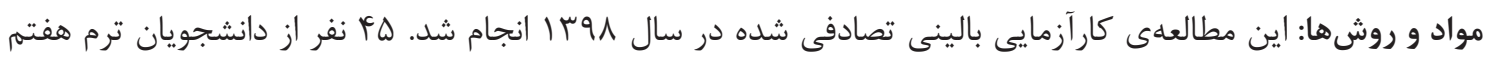

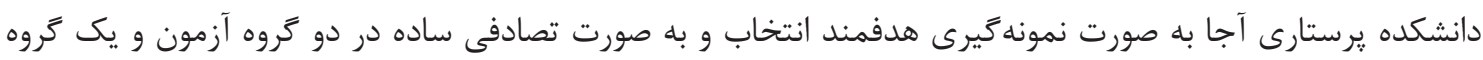

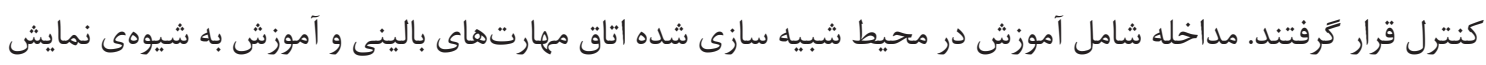

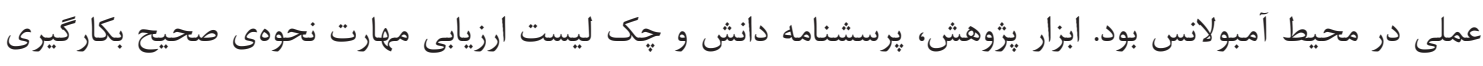

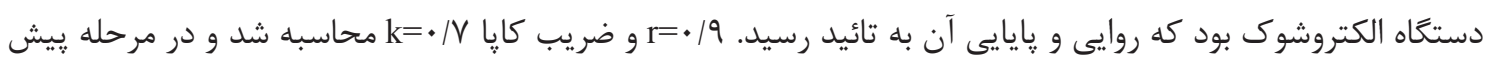

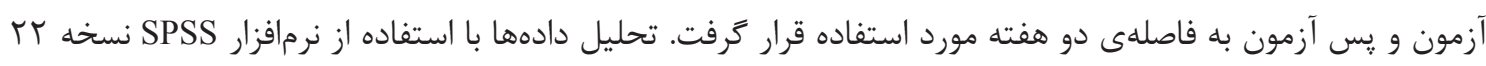
انجام كرديد. يافتها: ميانكين نمره دانش و مهارت در مرحله قبل از مداخله در سه كَروه تفاوت معنى دارى نداشت (ه • P> P)، وليكن

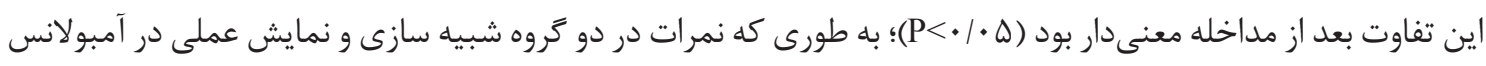

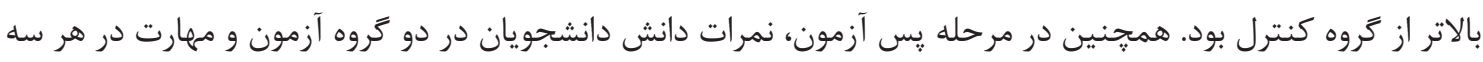

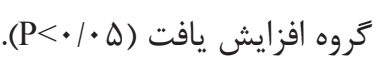

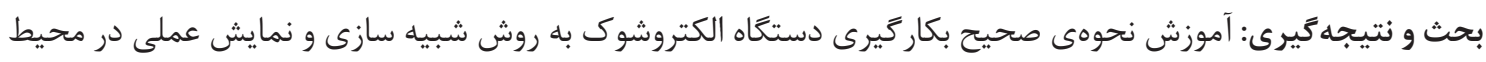

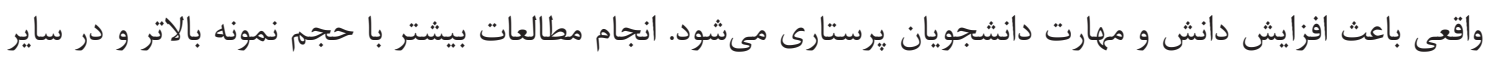
كروههاى مراقبت بهداشتى توصيه مىشود.

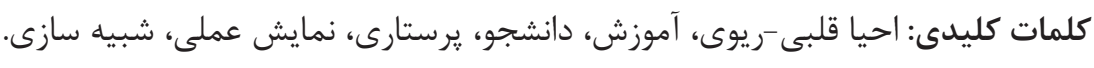

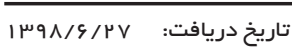

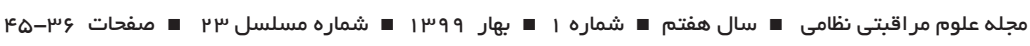

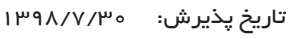

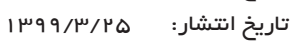


است (^). تكرار آموزش به كار كنان سيستمهاى مراقبت بهداشتى

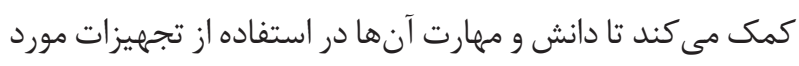

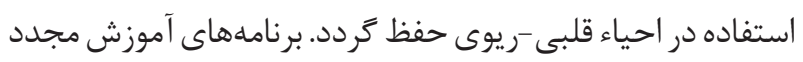

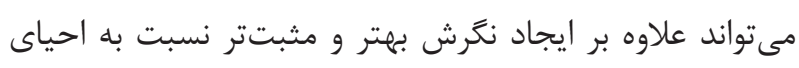

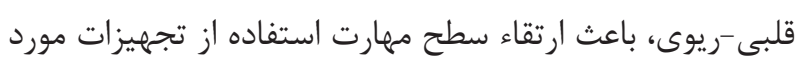

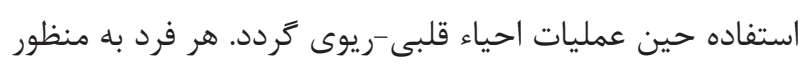
كذراندن دروس مربوط به احياى قلبى -ريوى پاياء (Basic Life)

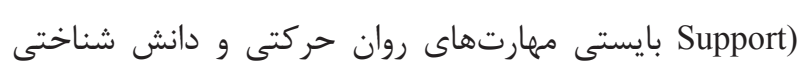

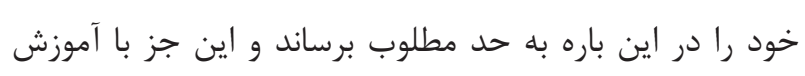
و تمرين مناسب ميسر نمى خردد (9) (9) در ايالات متحده ايجاد

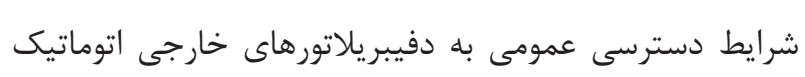
(Automated External Defibrillator) استفادهى استاندارد از اين دستخاه همزمان با احياى قلبى -ريوى

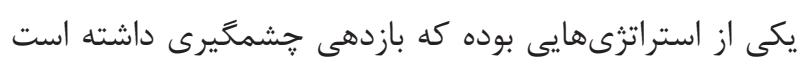

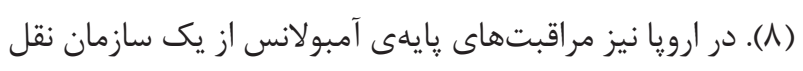

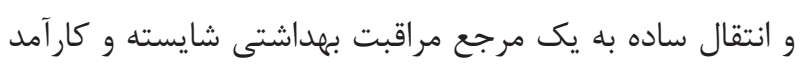

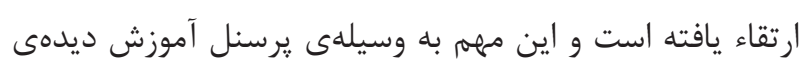

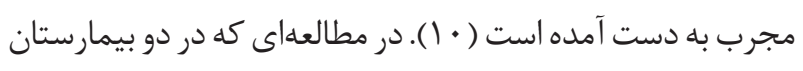

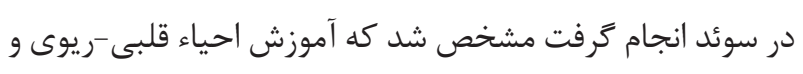

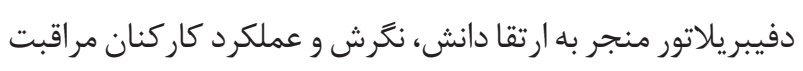

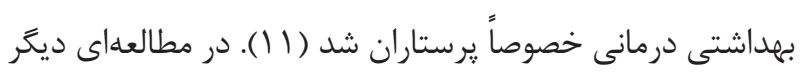
كه در بين تمامى مراكز بهداشتى و مراقبت اوليه در فنلاند انجام

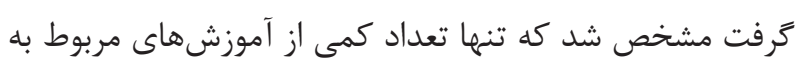
عمليات احياء قلبى-ريوى كافى و به صورت سيستماتيك بوده و

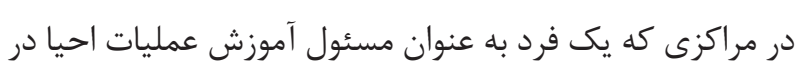

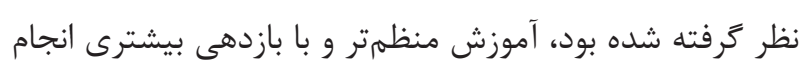

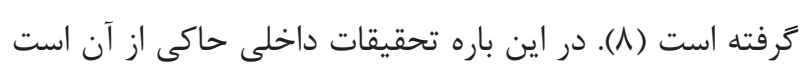

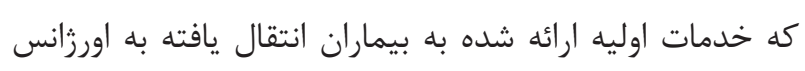

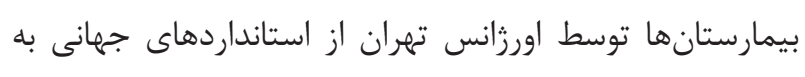

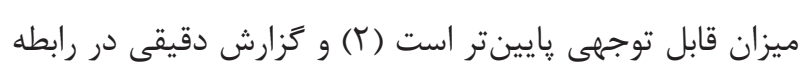

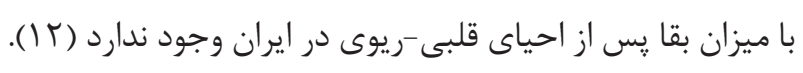

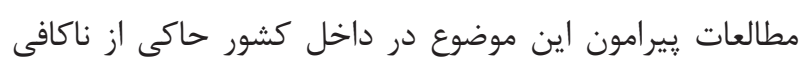

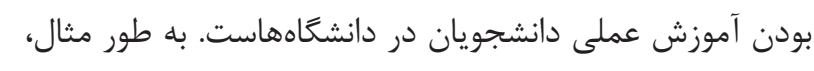

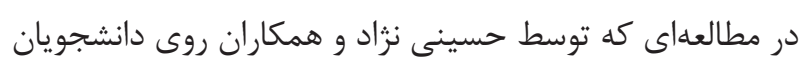

زندگى و يك تكنيك حفظ حيات جهت برقرارى جريان خون و

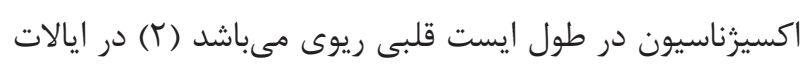

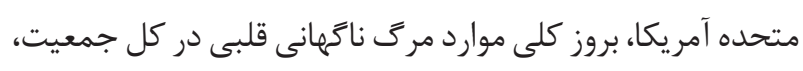

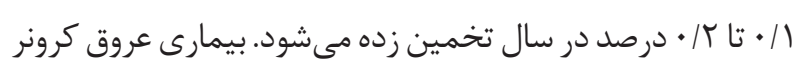

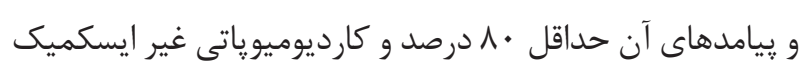

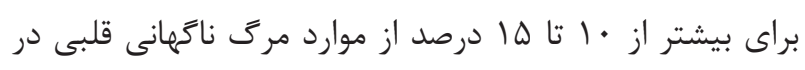

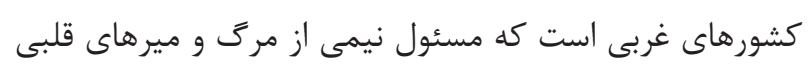

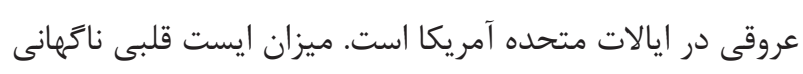

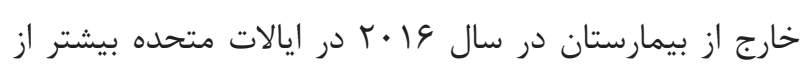

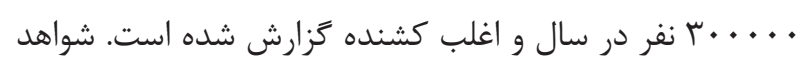
حاكى از آن است كه ميزان نجات در خارج از بيمارستان كمتر

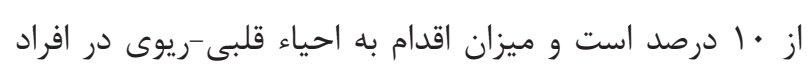

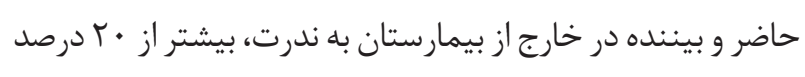

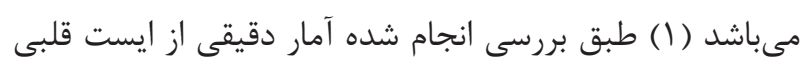

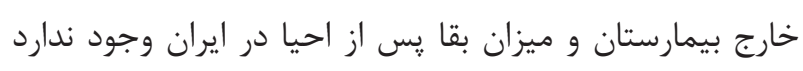

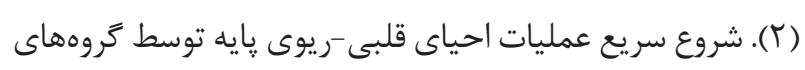

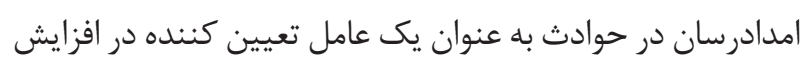
ميزان بقاى مصدومين محسوب مىشود (با). در صورتى كه عمليات

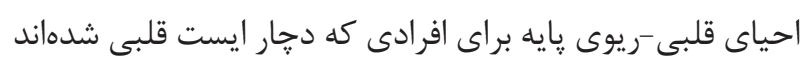

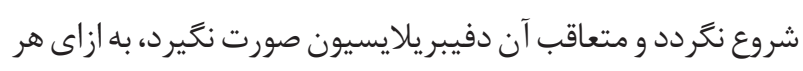

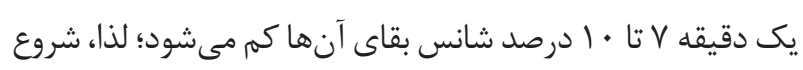

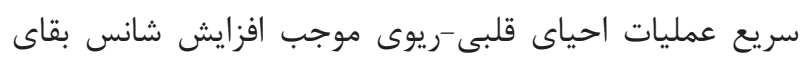

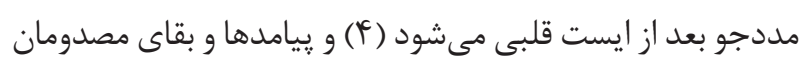

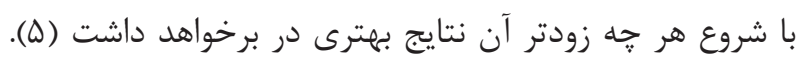

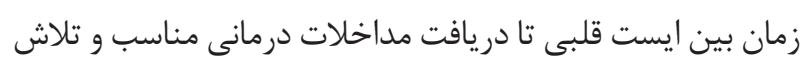
در جهت كوتاه كردن اين زمان يكى از اساسىترين و مؤثرترين

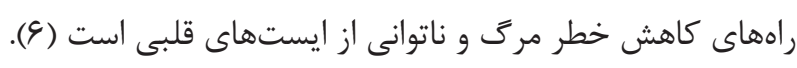

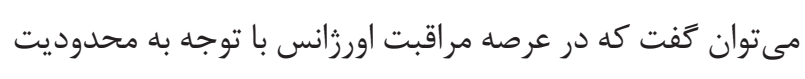

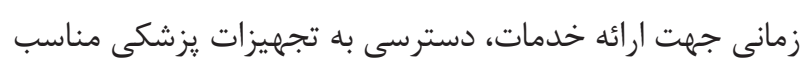

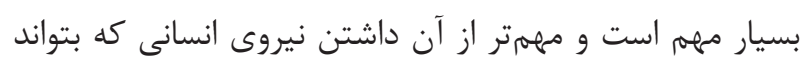
بهطور صحيح و مؤثر اين تجهيزات را بكار كيرد (V). لذا، مراكز

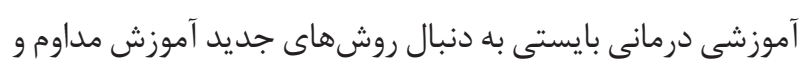

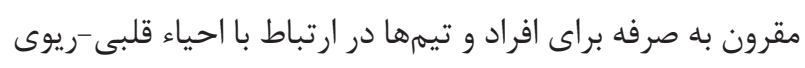
باشند و اين مهمم نيازمند آموزش سيستماتيك با شيوههاى مناسب 
مددجويان به مراكز درمانى ييشرفته صورت بخيرد و اين امر جز به

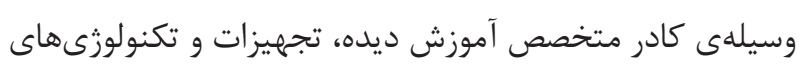

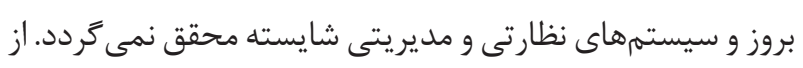

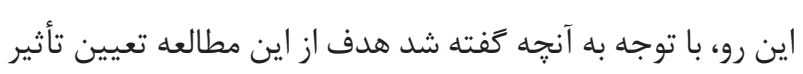

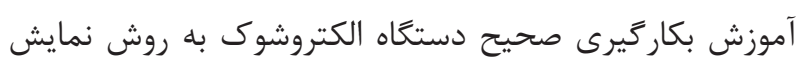

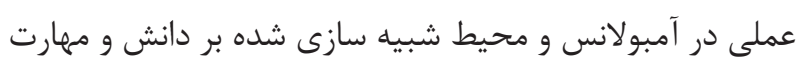

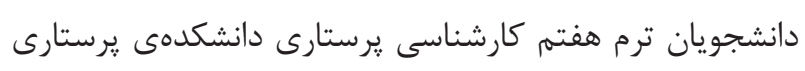

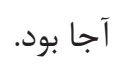

\section{مواد و روشها}

مطالعه حاضر از نوع كارآزمايى بالينى تصادفى شده بود كه در

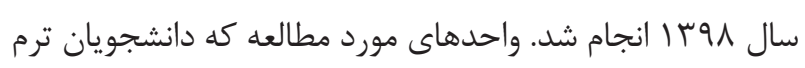

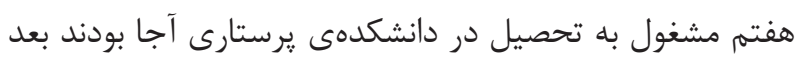

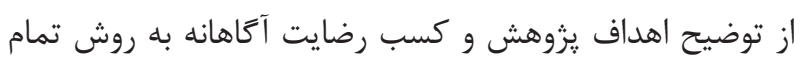

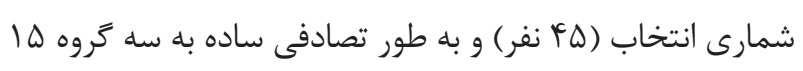

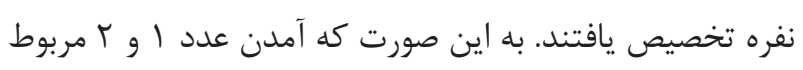

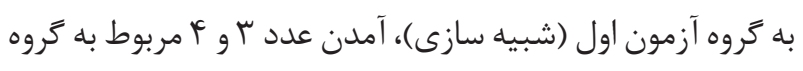

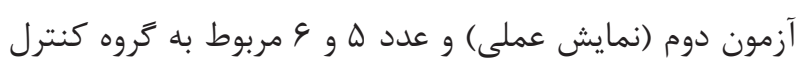

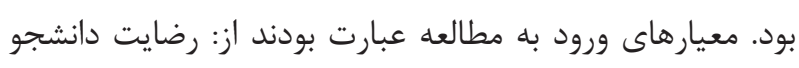

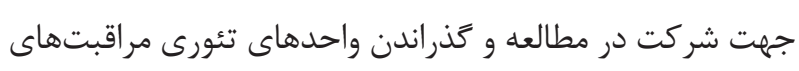

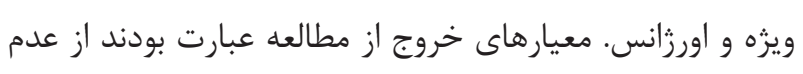

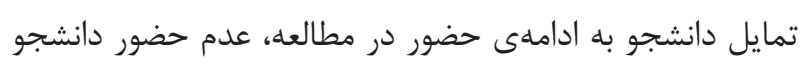

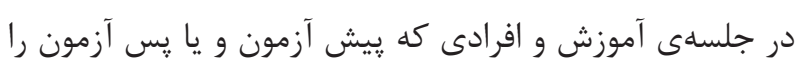

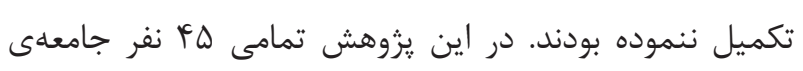

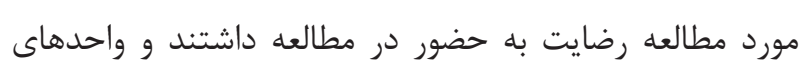
مورد يزوهش طى مطالعه ريزش نداشتند.

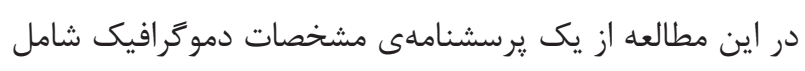

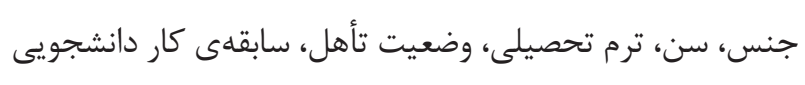

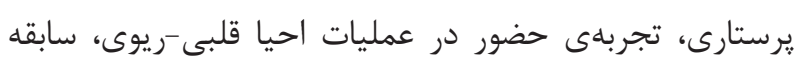

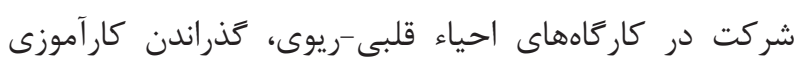
مراقبتهاى ويزه، تجربلى استفاده از دستخاه الكتروشوك بودياء

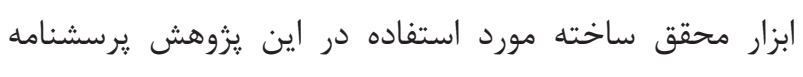

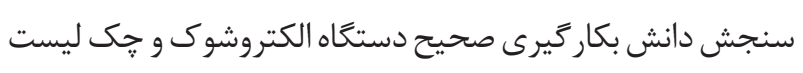

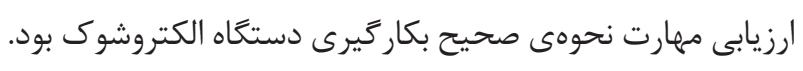

يرستارى در مازندران انجام شد، هيج يك از شركت كنندكان در

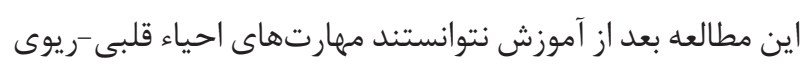

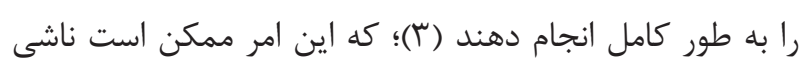

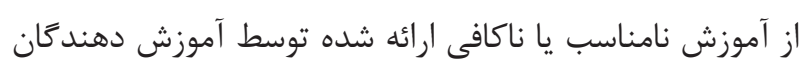

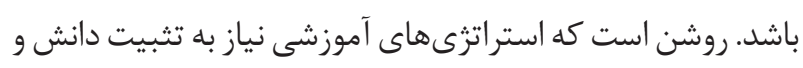

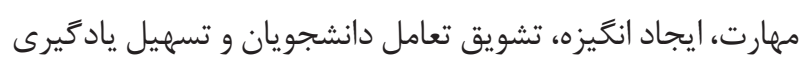

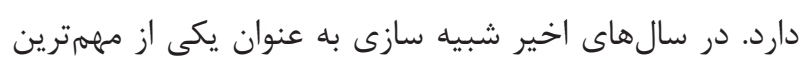

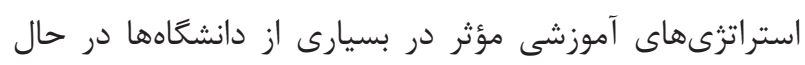

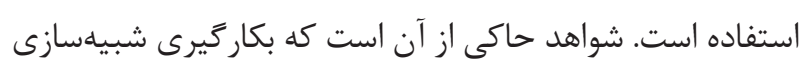

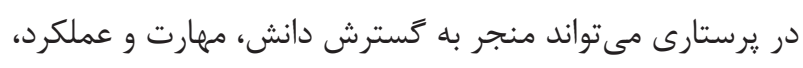

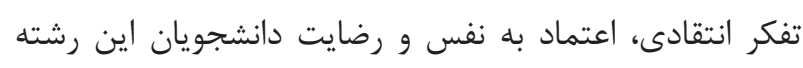
شود. براى نمونه، مطالعهاى كه توسط ليلى و همكاران به منظور

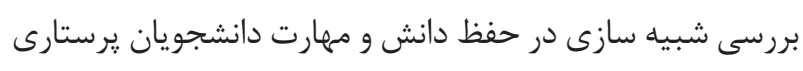

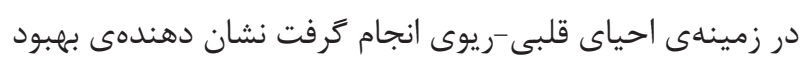

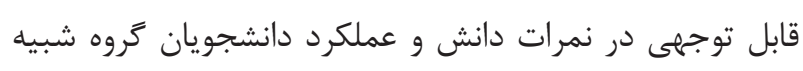
سازى نسبت به گروه سخنرانى بود (r).

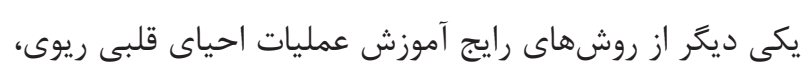

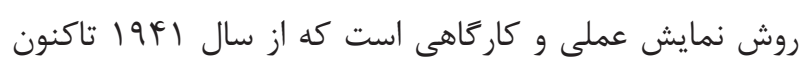

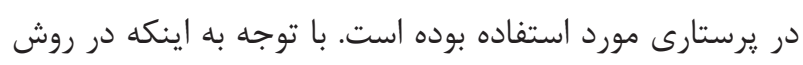

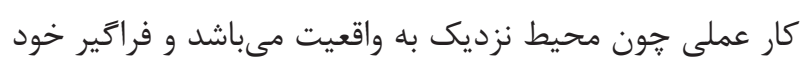
را در آن محيط فرض نموده و تمرين مى كند، يادَّيرى مى تواند

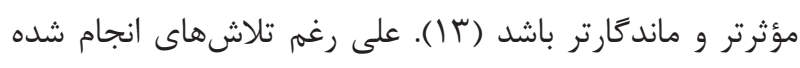

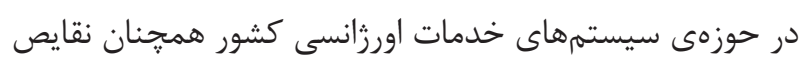

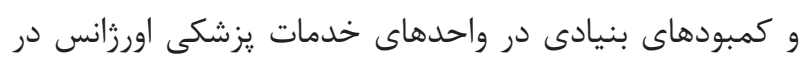
سازمانها از جمله مراكز بهداشتى درمانى نظامى نيز وجود دارد.

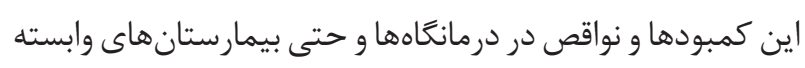
به ارتش جمهورى اسلامى ايران نيز به جشم مئى خورد. از جمله

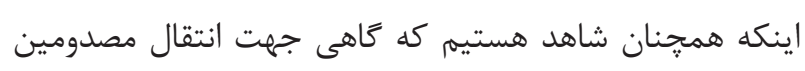
و بيماران از خودروهايى استفاده مىشود كه امكانات مورد نياز

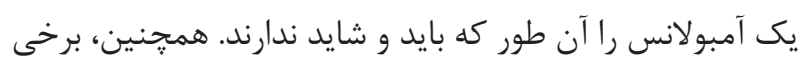

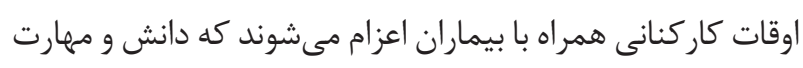

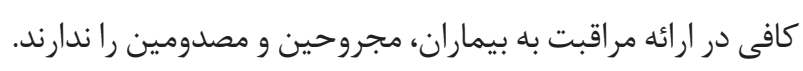

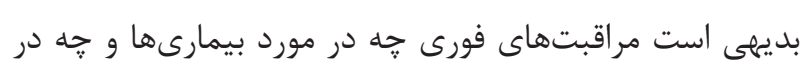
مورد مصدوميتها بايستى هم در صحنهى حادثه و هم حين انتقال 
واحدهاى مورد يزوهش پييرامون نحوهى صحيح بكار گيرى دستكاه

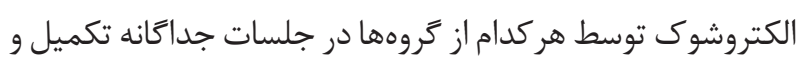

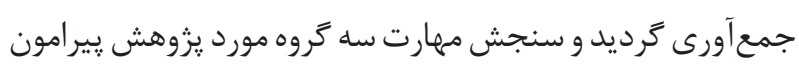

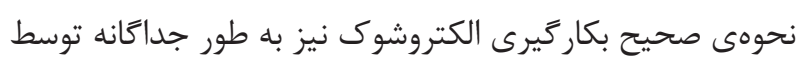

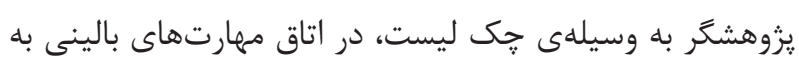

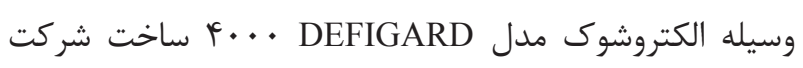
KAR/) بر روى مانكن نيم تنه احياى قلبى كريوى SCHILLER

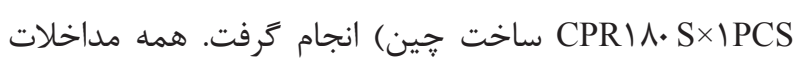

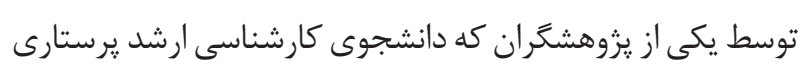

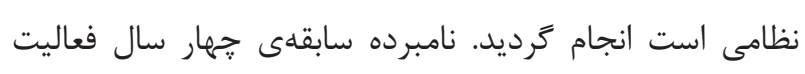

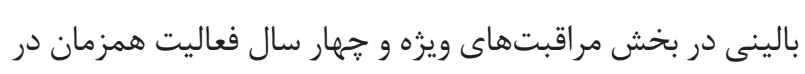

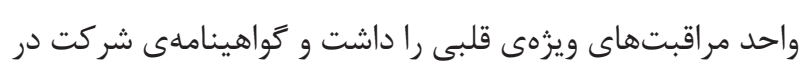

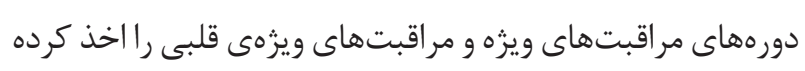
و طى اين دورهها كاربرى صحيح دستگاه الكتروشوك را رآموخته

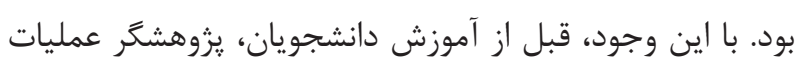

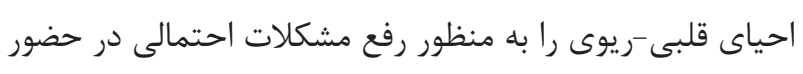

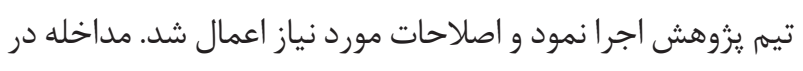

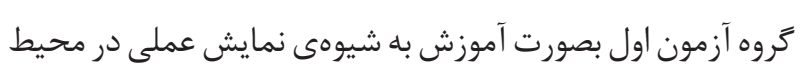

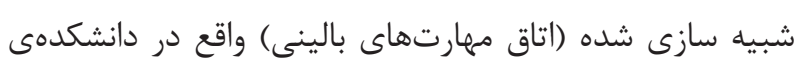

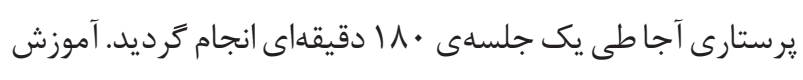

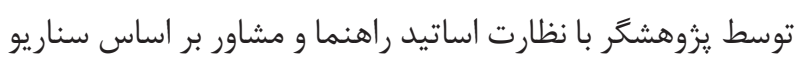

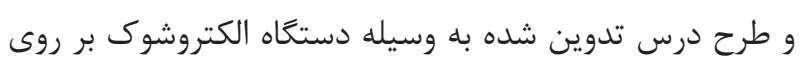
مانكن نيم تنه احياى قلبى ريوى صورت كرفت. اين مانكن از

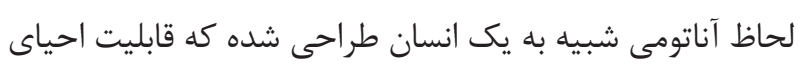

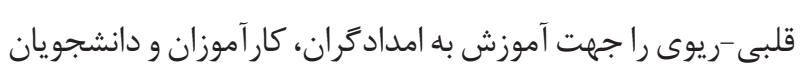

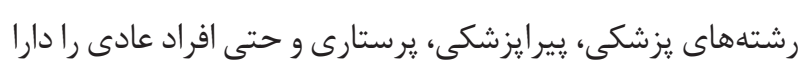

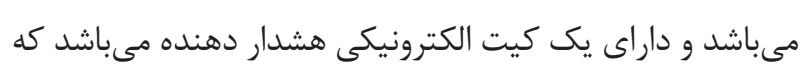

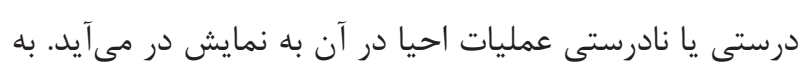

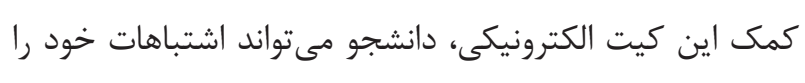
تصحيح و احياى قلبى -ريوى را به طور صحيح و اصولى فرا كيرد.

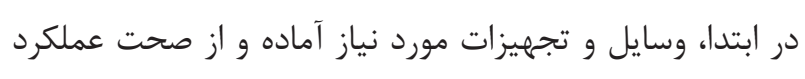

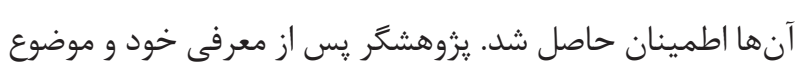

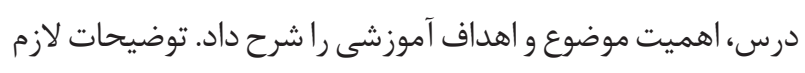

جهت بكار كيرى صحيح الكتروشوى حين انجام احيا قلبى-ريوى
يرسشنامهى دانش داراى • r سؤال جهار كزينهاى بود كه حداكثر

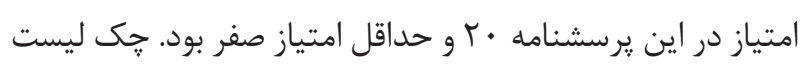
سنجش مهارت نحوهى صحيح بكارگيرى دستخاه الكتروشوى إنى

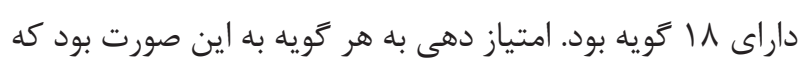

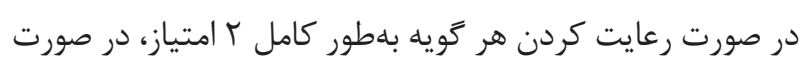
عدم رعايت كويهى مورد نظر صفر امتياز و در صورت انجام دادن

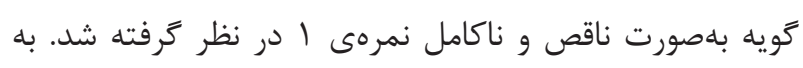

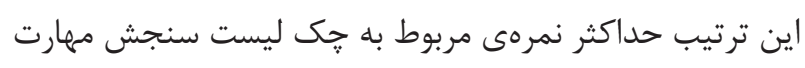
دستكاه الكتروشوى عب و حداقل نمره آن صفر بود. كسب نمرات بالاتر در يرسشنامه و جك ليست بيانكر بالاتر بودن و مطلوبتر

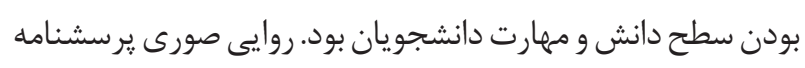

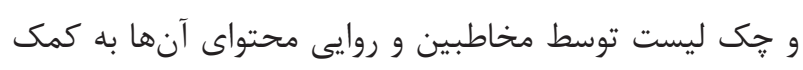
•ا نفر از متخصصان اين حوزه (جهار مربى كارشناس ارشد

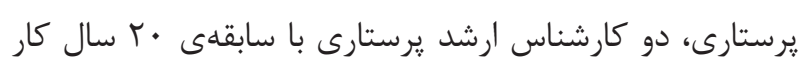

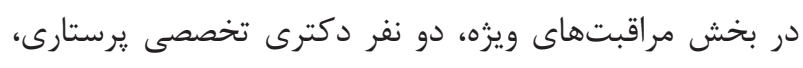

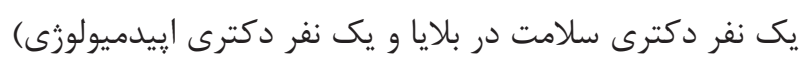

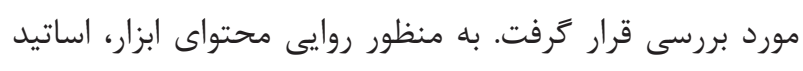
و صاحبنظران بر اساس معيارهاى رعايت دستور زبان، استفاده

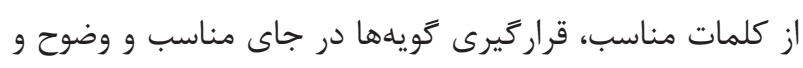

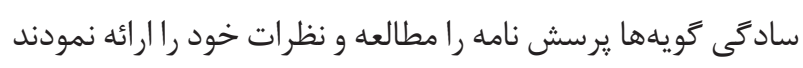

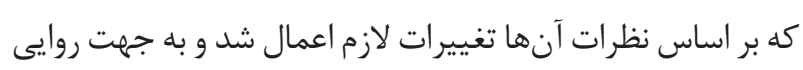

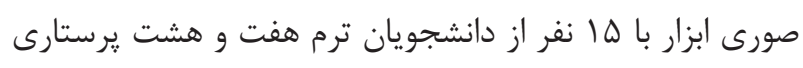
(خارج از سه كروه يانزده نفرهى انتخاب شده براى مطالعه) كه قبلاً

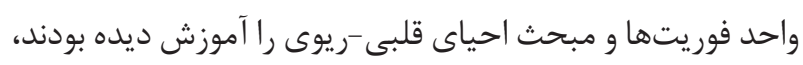
به صورت جهره به جهره مصاحبه شد و سطح دشوارى، ميزان

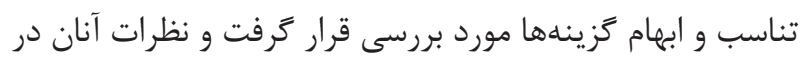

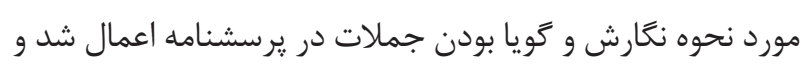

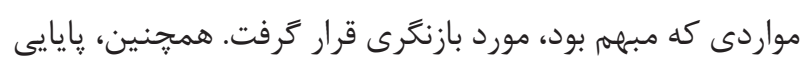

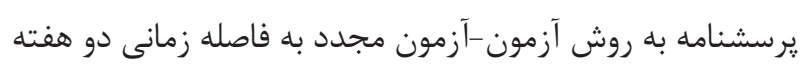

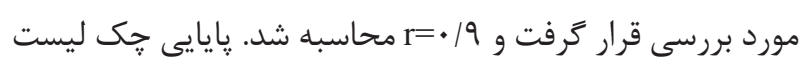
به روش بررسى يايايى ارزيابان كه به وسيلهى دو ارزياب همزمان

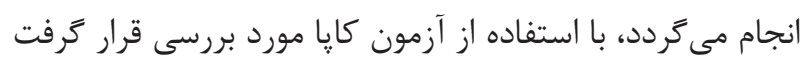
كه ضريب كايا k= k محاسبه كرديد. در مرحلهى قبل از مداخله يرسشنامهى مربوط به سنجش دابل مانش 
ييش آزمون و پِ آزمون به فاصلهى زمانى دو هفته صورت

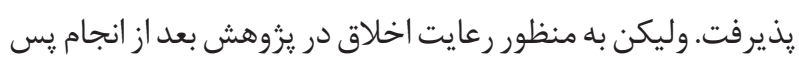

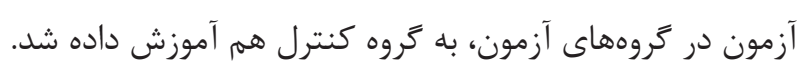

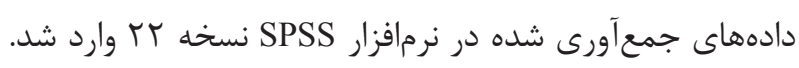

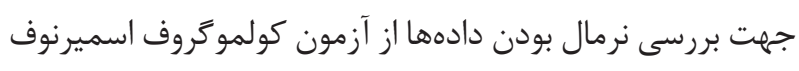

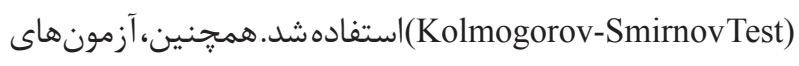

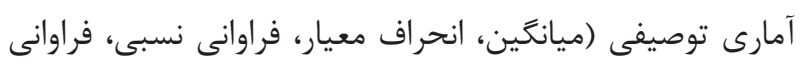

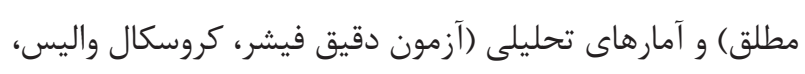
آزمون آنواى يك طرفه، ويلكاكسون) مورد استفاده قرار كرفتند.

$$
\text { سطح معنى دارى ه • P إن در نظر كرفته شد. }
$$

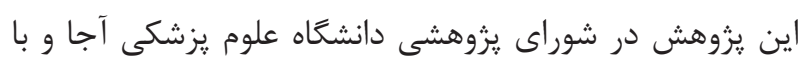

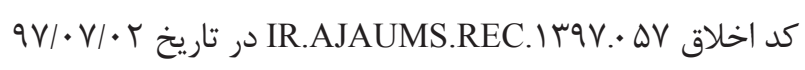
مورد تائيد قرار كرفت. در اين مطالعه، نكات اخلاقى بيانيه

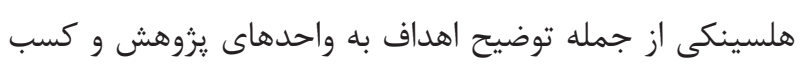

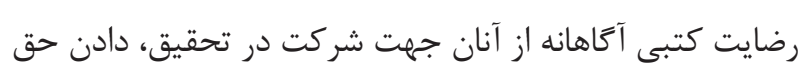

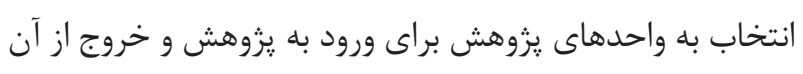

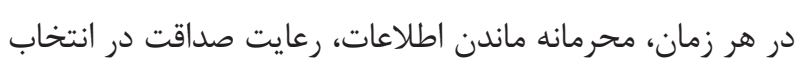
واحدهاى مورد يزوهش و جمع آورى و تجزيه و تحليل دادهها،

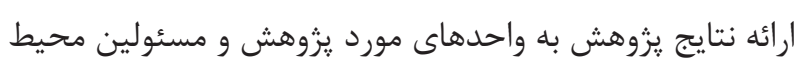

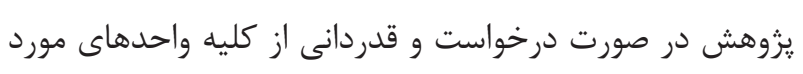
يزوهش و كليه مسئولين ذىربط كه همكارى داشتهاند، رعايت شد. رعايت اصول نشر و اخلاق در يزوهش و انتشار يافتههاى دئي مطالعه از ديكر تعهدات اصول كميته بين المللى اخلاق نشر نش اخلاقى يزوهشكَران (COPE) بود كه رعايت گرديد.

يافتهها

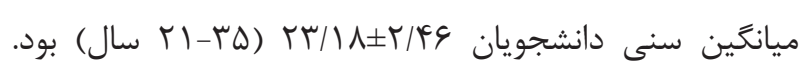
يافتهها حاكى از آن بود كه بين سه كَروه تفاوت معنى دارى از از

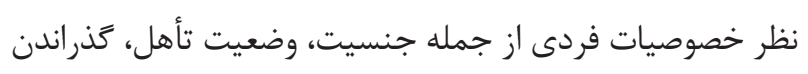
كارآموزى مراقبتهاى ويزه، سابقه كار دانشجويى يرستارى و و

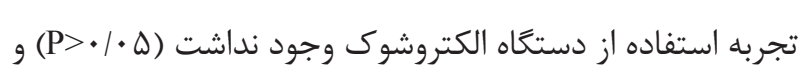

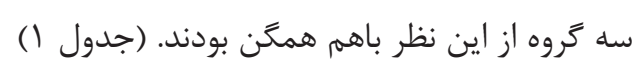

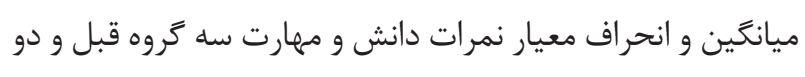
هفته بعد از مداخله در جدول ب و ب مقايسه شده است. آزمون
به صورت سخنرانى و همزمان نمايش عملى مطابق دستورالعمل

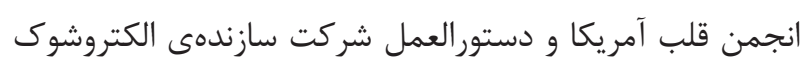

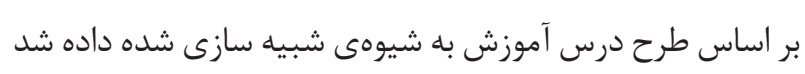

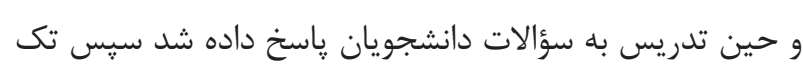
تك دانشجويان (ها نفر) از دستعاه الكتروشوك استفاده كردند و نقايص و مشكلات آنها رفع كرديد.

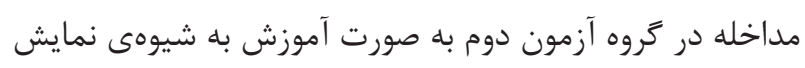

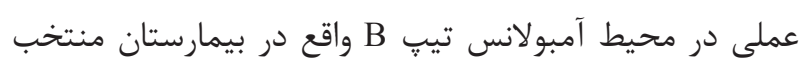

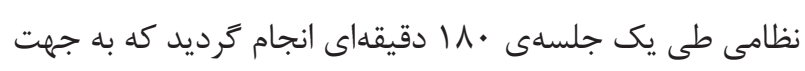
محدوديت فضاى كابين آمبولانس دانشجويان به سه كروه له نف نفره

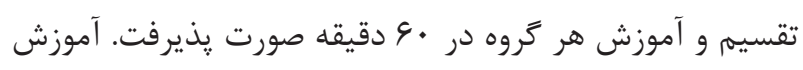

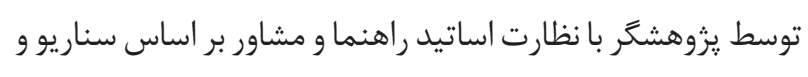
طرح درس تدوين شدهى آموزش به شيوهى نمايش عملى صورت

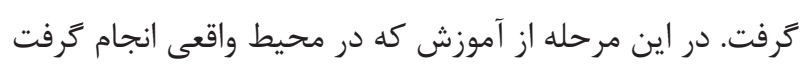

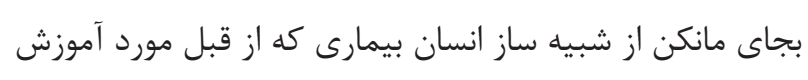

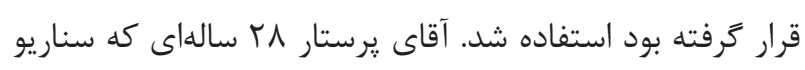

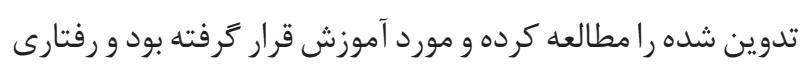

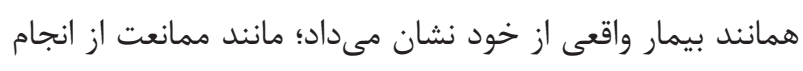

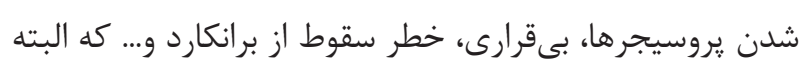

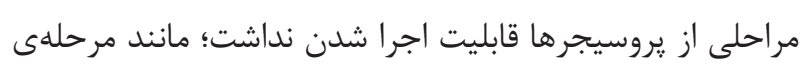

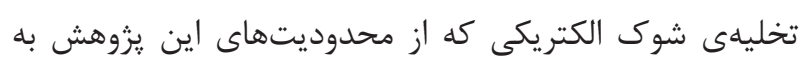

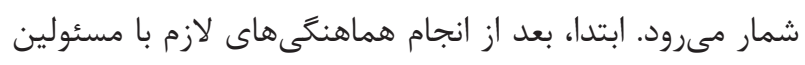

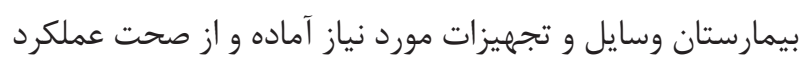
آنها اطمينان حاصل شد. يزوهشكَ يس از معرفى خود و موضوع درس، اهميت موضوع و اهداف آموزشى را شرح داد. موقعيت الهين مكانى و اجزاى دستكاه الكتروشوك و نحوهى صحيح بكاركيرى اهن اين دستخاه به روش نمايش عملى و با توضيحات شفاهى همزمان دمان

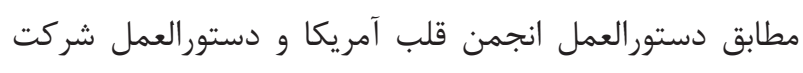
سازندهى الكتروشوك در فضاى آمبولانس آموزش داده شد و حين تدريس به سؤالات دانشجويان ياسخ داده شد. تك تك دانشجويان (ها نفر) در اين گروه نيز از دستعاه الكتروشوك استفاده كردند

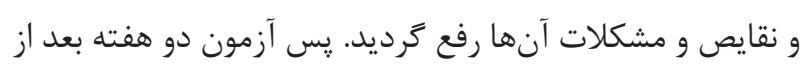
اتمام جلسات آموزشى انجام شد.

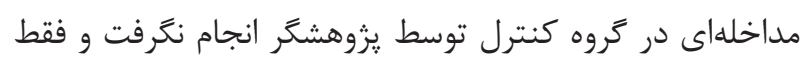


جدول ا- مشخصات فردى دانشجويان در كروههاى آزمون و كنترل

\begin{tabular}{|c|c|c|c|c|c|}
\hline نوع آزمون و سطح معنىدارى & $\begin{array}{c}\text { تعداد (درصد) } \\
\text { تعترل }\end{array}$ & تعدايش عملى (درصد) & محيط شبيدسازى شده & & متغير ها \\
\hline \multirow{2}{*}{$\begin{array}{c}\text { كاى اسكوئر } \\
\begin{array}{c}P=\cdot / T Y \\
\text { df }=r\end{array}\end{array}$} & $(99 / V) 1$. & ه (ז/س & ג & مرد & \multirow[b]{2}{*}{ جنسيت } \\
\hline & ه (ז/سז) & $(99 / \mathrm{V}) 1$. & $(F \in / V) V$ & زن & \\
\hline \multirow{2}{*}{$\begin{array}{c}\text { كاى اسكوئر } \\
P=1 \\
d f=r\end{array}$} & $(1 \mu / \mu) r$ & $(r \cdot) r$ & $(1 \% / r) r$ & متأهل & \multirow[b]{2}{*}{ وضعيت تأهل } \\
\hline & سו & سו & سו & مجرد & \\
\hline \multirow{2}{*}{$\begin{array}{c}\text { كاى اسكوئر } \\
P=1 \\
\text { df=r }\end{array}$} & $(f \& / V) V$ & $(f \cdot)^{q} q$ & $(f \cdot)^{q}$ & بلى & \multirow[b]{2}{*}{ كذراندن كارآموزى مراقبتهاى ويزه } \\
\hline & ( & (9.) 9 & $(9 \cdot) 9$ & خير & \\
\hline \multirow{2}{*}{$\begin{array}{c}\text { كاى اسكوئر } \\
\begin{array}{c}P=\cdot / r d \\
d f=r\end{array}\end{array}$} & $(Y G / V) F$ & ( & $(Y G / V) F$ & 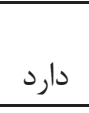 & \multirow[t]{2}{*}{ سابقه كار دانشجويى يرستارى } \\
\hline & $(V / \mu) 11$ & $(\varphi \& / V) V$ & $(V / \mu) 11$ & 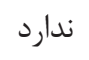 & \\
\hline \multirow{2}{*}{ 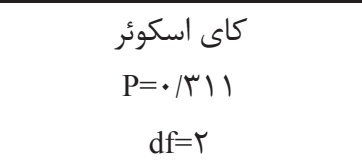 } & $(r \cdot)^{\mu}$ & $\left(l^{k} \cdot\right)^{q}$ & r & مارد & \multirow[b]{2}{*}{ تجربه استفاده از دستگاه الكتروشوك } \\
\hline & $(\Lambda \cdot) \mid r$ & (9. $) 9$ & س & 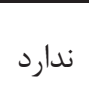 & \\
\hline
\end{tabular}

جدول r- مقايسه ميانكين و انحر اف معيار دانش نحوهى صحيح بكاركيرى الكتروشوى دانشجويان برستارى قبل و دو هفته بعد از مداخله در سه كروه

كرو

مرحله

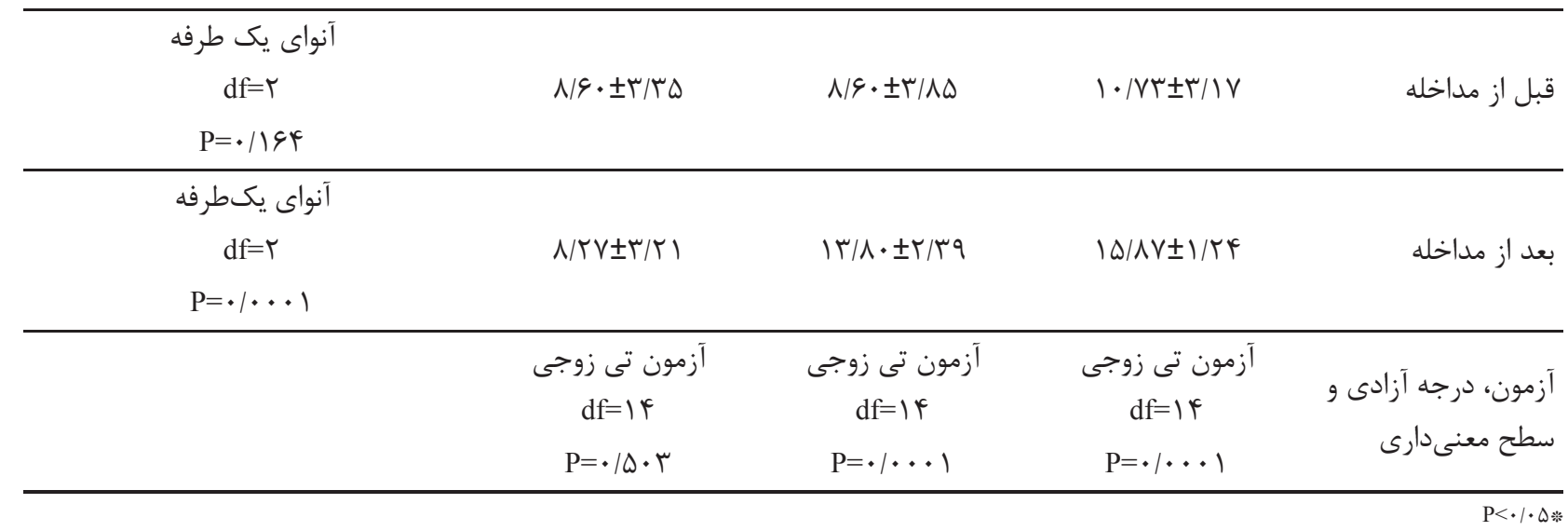

كنترل بود. همجنين آزمون كروسكال واليس نشان داد كه دو هفته بعد از مداخله ميانگين نمره مهارت نيز در سه گروه از نظر آمارى تفاوت معنى دارى داشت ( ( P= (P) و نمرات دو گروه آزمون بالاتر از گروه كنترل بود. آزمون تى زوجى نشان داد ميانگين نمرهى دانش قبل و دو هفته بعد از مداخله در زروه آزمون 1 و و

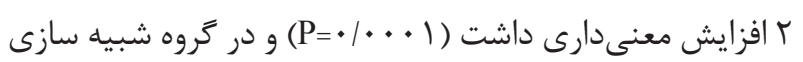

آنواى يكطرفه نشان داد كه ميانخين نمره دانش و مهارت قبل از مداخله در سه گروه از نظر آمارى تفاوت معنى دارى نداشت

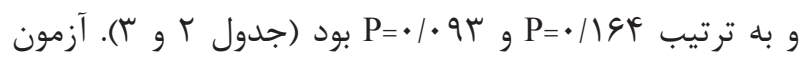
آنواى يكطرفه نشان داد كه دو هفته بعد از مداخله ميانگين نمره دانش در سه گروه از نظر آمارى تفاوت معنى دارى داشت

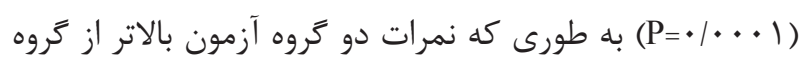


جدول بـ مقايسه ميانغَين رتبهها، ميانكَين و انحراف معيار مهارت نحوهى صحيح بكار كيرى الكتروشوك دانشجويان برستارى قبل و دوهفتم بعد از مداخله در سه

\begin{tabular}{|c|c|c|c|c|c|c|c|}
\hline \multirow{4}{*}{ آزمون، درجه آزادى سطح معنىدارى } & \multicolumn{7}{|c|}{ تروه } \\
\hline & \multicolumn{2}{|r|}{ كنترل } & \multicolumn{2}{|c|}{ شبيهسازى } & \multicolumn{2}{|c|}{ نمايش عملى } & \multirow{3}{*}{ مرحله } \\
\hline & ميانَين & ميانغين土|نحراف & ميانگين & ميانكَين土|نحراف & ميانگين & ميانغين||نحراف & \\
\hline & ر رتبهها & معيار & رتبهها & معيار & رتبهها & معيار & \\
\hline \multicolumn{8}{|l|}{ آنواى يك طرفه } \\
\hline$d f=r$ & - & $I V / V \Psi \pm \Psi / F V$ & - & $19 / \mathcal{E} \vee \pm r / 11$ & - & $r \mid / \cdot \pm \Delta / \cdot q$ & قبل از مداخله \\
\hline \multicolumn{8}{|l|}{$\mathrm{P}=\cdot / \cdot 9 \mu$} \\
\hline \multicolumn{8}{|l|}{ كروسكال واليس } \\
\hline$d f=r$ & $\mid r / \cdot V$ & Tr/TrEV/qV & rq/q. & $T / / \cdots \pm F / \Lambda F$ & $r \varepsilon / \cdot r$ & $r \cdot / l \Psi \pm F / v g$ & بعد از مداخله \\
\hline \multicolumn{8}{|l|}{$\mathrm{P}=\cdot \mid \cdot \cdot 1$} \\
\hline & \multicolumn{2}{|c|}{ ويلكاكسون } & \multicolumn{2}{|c|}{ ويلكاكسون } & \multicolumn{2}{|c|}{ ويلكاكسون } & \multirow{3}{*}{ و آزمون درجه آزادى معنى دارى } \\
\hline & \multicolumn{2}{|c|}{$Z=-r / \Delta \mid r$} & \multicolumn{2}{|c|}{$Z=-r / \mathcal{\Psi} \mid \Delta$} & \multicolumn{2}{|c|}{$Z=-r / \cdot V V$} & \\
\hline & \multicolumn{2}{|r|}{$\mathrm{P}=\cdot / \cdot 1 \mathrm{~T}$} & \multicolumn{2}{|r|}{$\mathrm{P}=\cdot \mid \cdot \cdot 1$} & \multicolumn{2}{|c|}{$\mathrm{P}=\cdot / \cdot r$} & \\
\hline
\end{tabular}

داشته باشد. همجنين، يافتههاى اين مطالعه نشان داد كه مهارت واحدهاى مورد يزوهش در سه گروه كه قبل از مداخله تفاوت

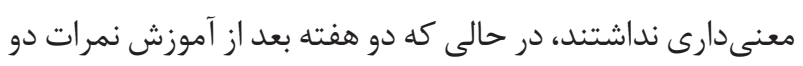

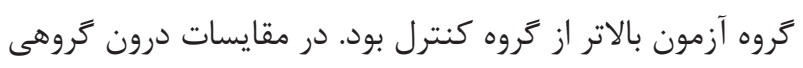
هم نمرات مهارت سه گروه آزمون و كنترل در مرحله يس آزمون بالاتر از مرحله ييش آزمون بود؛ بنابراين مىتوان كفت آموزش بكارگيرى صحيح دستخاه الكتروشوك در محيط شبيه سازى و نمايش عملى در آمبولانس مىتواند بر سطح مهارت دانشجويان يرستارى اثر مثبتى داشته باشد. همان طور كه در يافتهها نشان داده شد در نمرات مهارت گروه كنترل نيز تغيير معنى دارى ايجاد

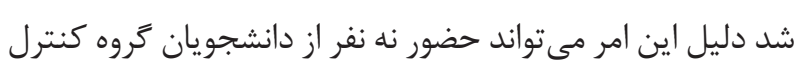
در كارورزى مراقبت ويزه يرستارى و فوريتهاى يزشكى در بازه زمانى دو هفتهاى بين يیش آزمون و يس آزمون باشد در حالى كه

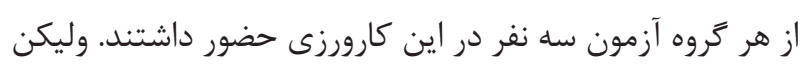
همان طور كه در يافتهها نشان داده شد نمرات دو گروه آزمون بالاتر از زروه كنترل بود. نتايج به دست آمده در اين مطالعه با مطالعه كاوندر و همكاران

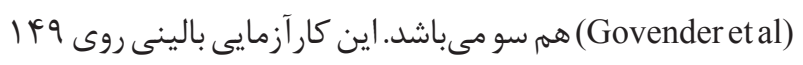
ييرايزشك با هدف بررسى دو برنامهى آموزشى اجراى عمليات

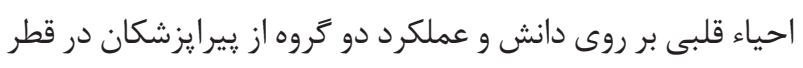
انجام گرديد نشان داد كه افرادى كه تحت برنامهى آموزشى ويزه
بيشتر بود در حالى كه در گروه كنترل تفاوت معنىدارى ايجاد

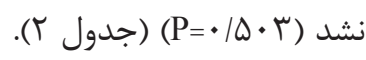
همجنين، آزمون ويلكاكسون نشان داد كه ميانگين نمرهى مهارت

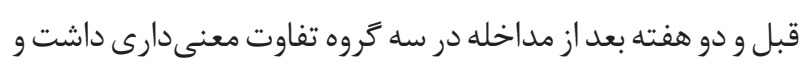

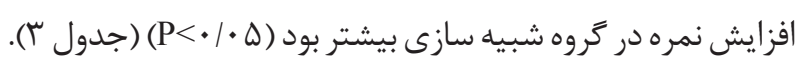

\section{بحث و نتيجه كيرى}

اين مطالعه با هدف بررسى تأثير آموزش بكارگيرى صحيح دستخاه الكتروشوك به روش نمايش عملى در آمبولانس و محيط شبيه سازى شده بر دانش و مهارت دانشجويان ترم هفتم كارشناسى يرستارى دانشكدهى يرستارى آجا انجام شد. يافتههاى اين مطالعه نشان داد كه دانش واحدهاى مورد يزوهش كه قبل از مداخله در زروههاى آزمون ا و r تفاوت معنى لمارى نداشت و كروهها از اين نظر همعن بودند. در حالى كه دو هفته بعد از آموزش نمرات در دو زروه آزمون بالاتر از زروه كنترل بود. در مقايسات درون گروهى هم نمرات دانش دو گروه آزمون در مرحله يس آزمون برون بالاتر از مرحله بيش آزمون بود، در حالى كه در گروه كنترل ميانغين نمرهى دانش ييش آزمون و دو هفته بعد از آن تفاوت معنى دارى نداشت. لذا، به نظر مىرسد آموزش بكارگيرى صحيح دستخاه

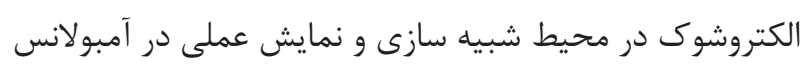

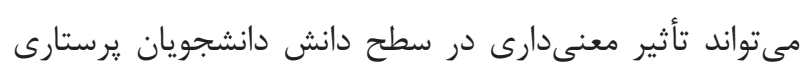


استفاده از شيوههاى متنوع آموزش احياء قلبى -ريوى جهت ارتقاء

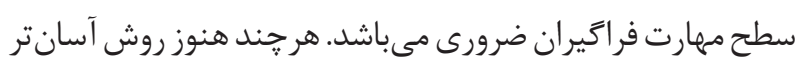

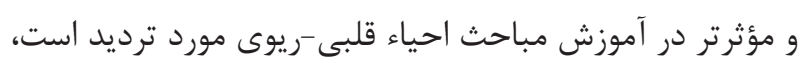

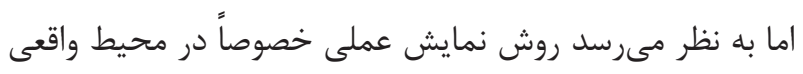

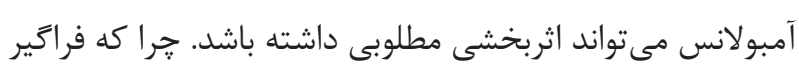

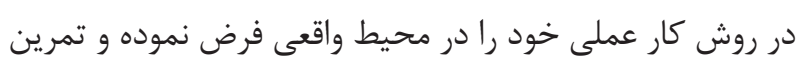

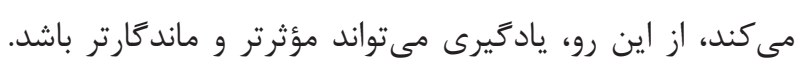

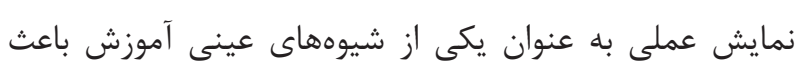

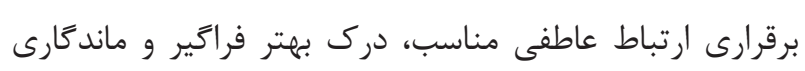

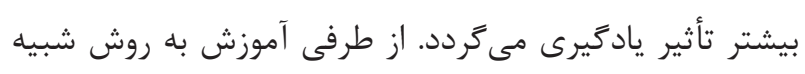

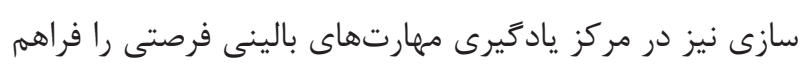

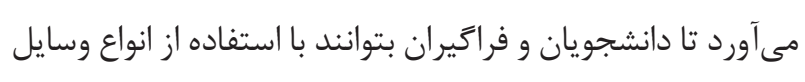

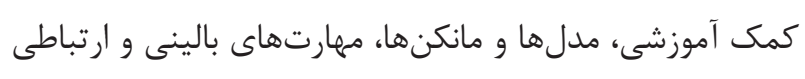

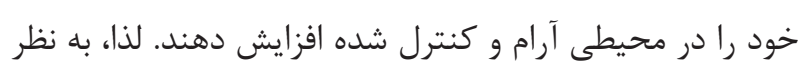

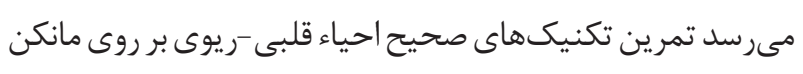

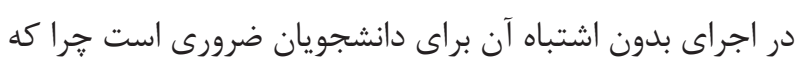
با تمرين در محيطهاى شبيه سازى شده مىتوان بسيارى از بدرئ

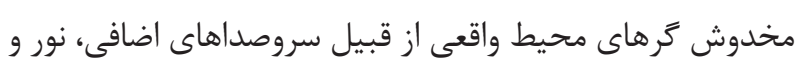

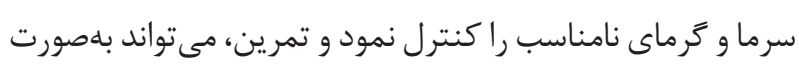
مكرر و نامحدود و به دور از ترس از صدمه به بيمار واقعى باشد.

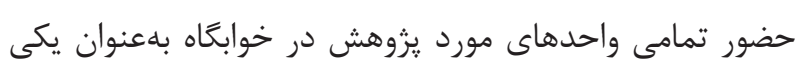

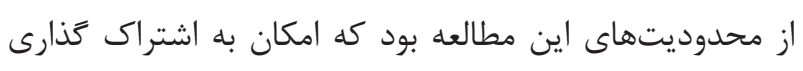

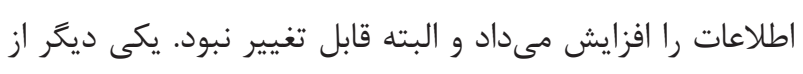

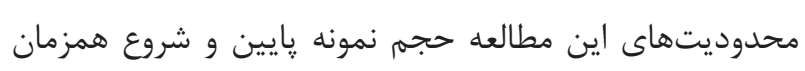

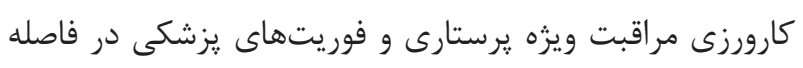

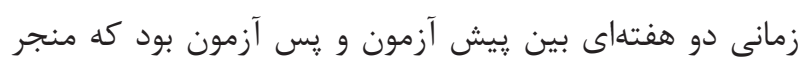

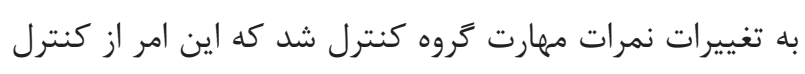

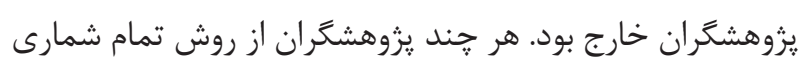

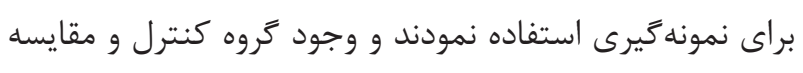

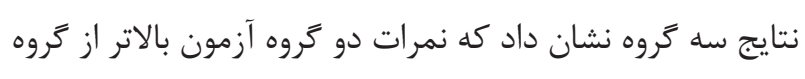

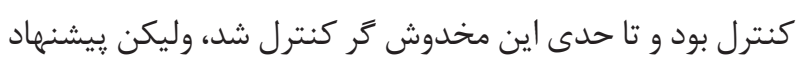

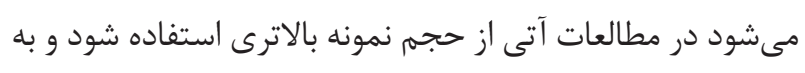

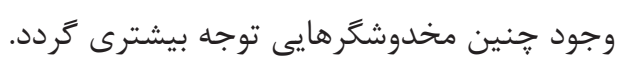

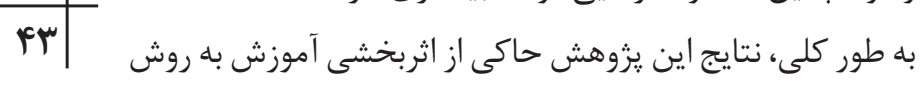

(نمايش عملى و شبيه سازى) قرار گرفته بودند، 9 • V درصد از

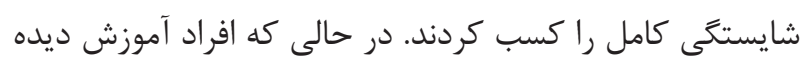

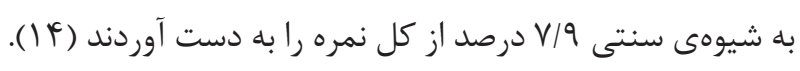

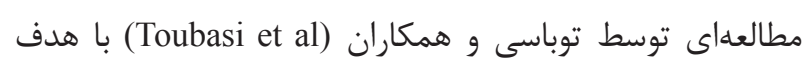
بررسى تأثير آموزش اجراى عمليات احياء قلبى -ريوى در محيط توبط شبيه سازى شده بر مهارت يرستاران در اردن انجام شد كه نتايج

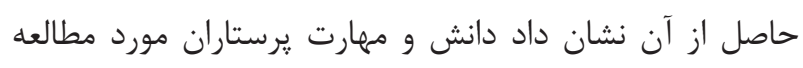

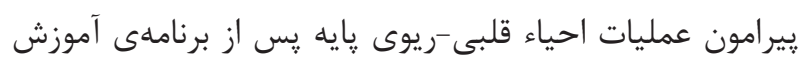
در محيط شبيه سازى شده بلهورت خشمخًيرى افزايش يافته

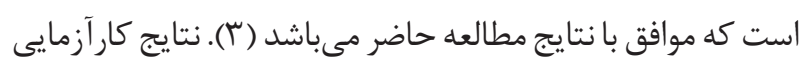
بالينى كه توسط عليمحمدى و همكاران با هدف مقايسه اثربخشى مونى

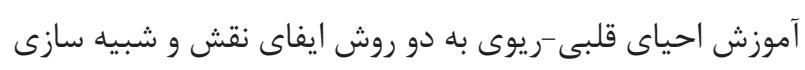

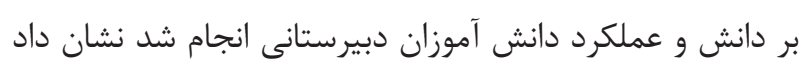

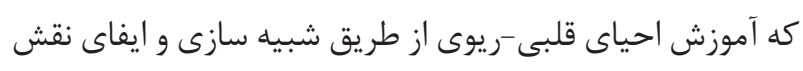

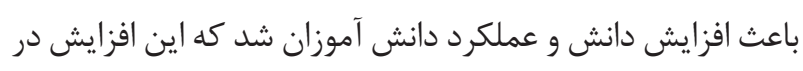

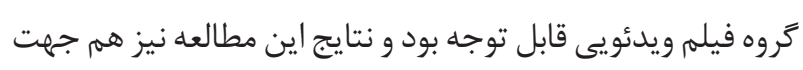

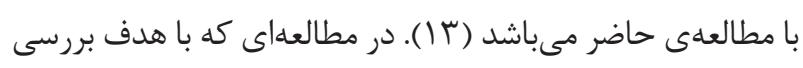

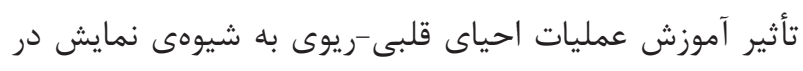

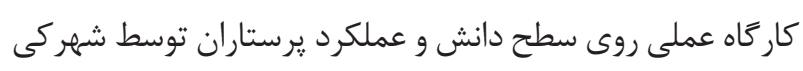

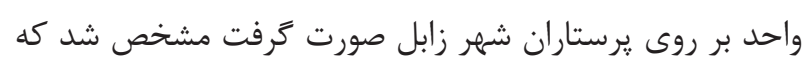

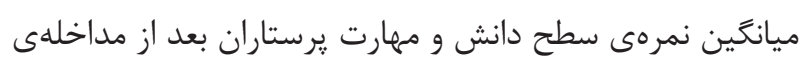

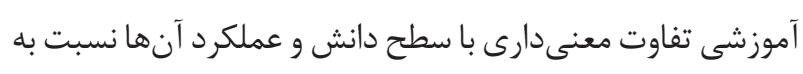

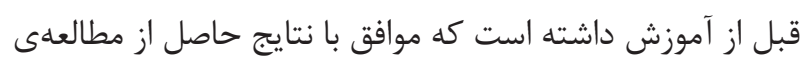

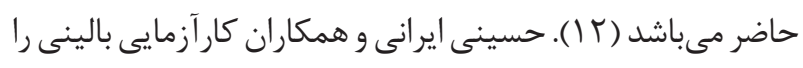

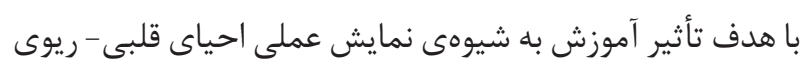

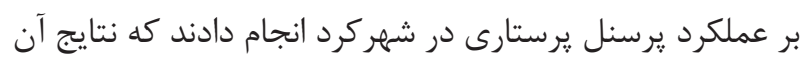

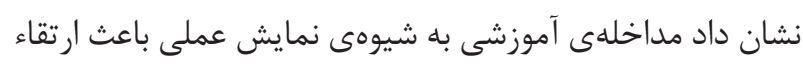

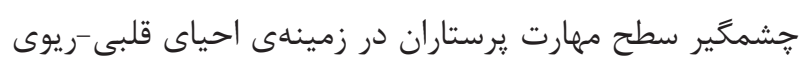
مى گردد كه باز هم موافق با نتايج مطالعهى حاضر مى بـاشد (بار).

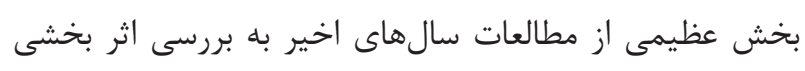
روشهاى آموزشى مختلف در ايجاد يادَيرى يايدار يرداختهاند.

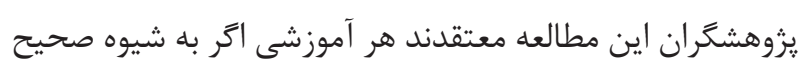

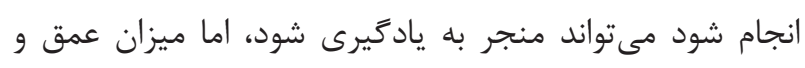
پايدارى يادَيرى در روشهاى مختلف آموزشى متفاوت است. 


\section{تشكر و قدردانى}

اين مقاله برگرفته از پايان نامه كارشناسى ارشد رشته يرستارى

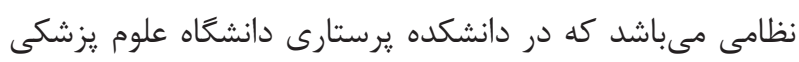
آجا به شماره ثبت بVY

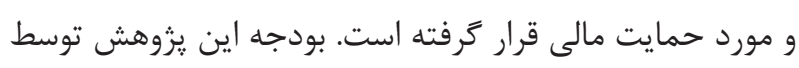
دانشعاه علوم يزشكى آجا تأمين شده است. بدين وسيله از كليه

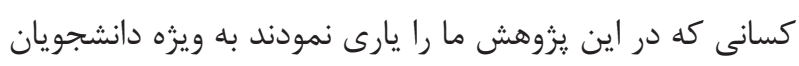

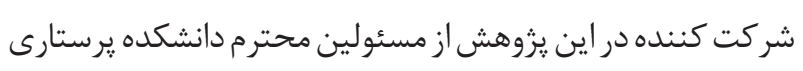
و دانشعاه علوم يزشكى آجا و بيمارستان منتخب نظامى كمال تشكر و قدردانى را داريم.

تضاد منافع

بدين وسيله نويسندكان تصريح مىنمايند كه هيج گونه تضاد منافعى در خصوص مطالعه حاضر وجود ندارد.

\section{References}

1- Delavari A, Mahmoodi G, Shams E. [Assesing performance of the EMS in Tehran in 2012]. Iran J Crit Care Nurs. 2015;22(6).

2- Bidari A, Abasi S, Farsi D, Saeidi H, Mofidi M, Radmehr M. [Evaluation of pre hospital emergency operation in transmitted patients to Rasool hospital]. J Tabriz Univ Med Sci. 2011;29(3):346.

3- Fallahinia G, Daneshgari lotf M, Borzo S, Moghimbeighi A, Sokuti T. Comparing the Effects of CPR Teaching Using Two Methods, Practical with Model and Film, on the Knowledge and Performance of Aid Groups in Hamadan, Iran. Scie J Hamedan Nursing \& Midwifery Faculty. 2016;24(1):9-15. http://dx.doi. org/10.20286/nmj-24012

4- Travers AH, Rea TD, Bobrow BJ, Edelson DP, Berg RA, Sayre MR, et al. Part 4: CPR overview: 2010 American Heart Association Guidelines for Cardiopulmonary Resuscitation and Emergency Cardiovascular Care. Circulation. 2010;122(18 Suppl 3):S67684. http://dx.doi.org/10.1161/CIRCULATIONAHA.110.970913 www.ncbi.nlm.nih.gov/pubmed/20956220

5- Roppolo LP, Heymann R, Pepe P, Wagner J, Commons B, Miller $\mathrm{R}$, et al. A randomized controlled trial comparing traditional training in cardiopulmonary resuscitation (CPR) to self-directed CPR learning in first year medical students: The two-person CPR study. Resuscitation. 2011;82(3):319-25. http://dx.doi. org/10.1016/j.resuscitation.2010.10.025 www.ncbi.nlm.nih.gov/ pubmed/21146914

6- Kudenchuk PJ, Stuart R, Husain S, Fahrenbruch C, Eisenberg
شبيه سازى و نمايش عملى در آمبولانس در خصوص بكارگيرى صحيح دستخاه الكتروشوك مىباشد و اين دو روش مىتواند منجر به افزايش دانش و مهارت دانشجويان يرستارى در اين زمينه گردد. لذا، توصيه مىشود اين روشهاى آموزشى به طور جدىتر در كوريكولوم دانشجويان يرستارى مدنظر قرار گيرد و مدرسين از اين شيوهها براى آموزش يروسيجرهاى عملى خصورياً احيا قلبى-ريوى بيشتر بهره گيرند. با توجه به نياز مبرم وجود

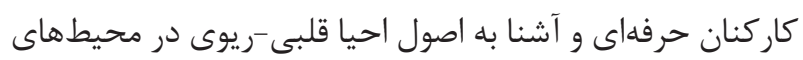
ييش بيمارستانى از جمله آمبولانس استفاده از اين روشها براى دورههاى بازآموزى كاركنان نيز توصيه مىشود. انجام مطالعات بيشتر با حجم نمونه بالاتر خصوصاً در محيط آمبولانس توصيه مىشود. همجنين، يِشنهاد مىشود در مطالعات آتى بازه زمانى

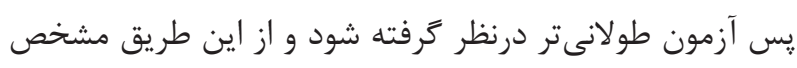
شود كه كدام روشها ماندًَارى بيشترى دارند.

M. Treatment and outcome of out-of-hospital cardiac arrest in outpatient health care facilities. Resuscitation. 2015;97:97-102. http://dx.doi.org/10.1016/j.resuscitation.2015.08.025 www.ncbi. nlm.nih.gov/pubmed/26476198

7- Koster RW, Baubin MA, Bossaert LL, Caballero A, Cassan P, Castren M, et al. European Resuscitation Council Guidelines for Resuscitation 2010 Section 2. Adult basic life support and use of automated external defibrillators. Resuscitation. 2010;81(10):127792. http://dx.doi.org/10.1016/j.resuscitation.2010.08.009 www. ncbi.nlm.nih.gov/pubmed/20956051

8- Vinker S. Out of hospital Cardio-pulmonary arrest - Is there a role for the primary healthcare teams? Isr J Health Policy Res. 2017;6(1):36. http://dx.doi.org/10.1186/s13584-017-0161-4 www. ncbi.nlm.nih.gov/pubmed/28659194

9- Abolfotouh MA, Alnasser MA, Berhanu AN, Al-Turaif DA, Alfayez AI. Impact of basic life-support training on the attitudes of health-care workers toward cardiopulmonary resuscitation and defibrillation. BMC Health Serv Res. 2017;17(1):674. http:// dx.doi.org/10.1186/s12913-017-2621-5 www.ncbi.nlm.nih.gov/ pubmed/28938914

10- Sjolin H, Lindstrom V, Hult H, Ringsted C, Kurland L. What an ambulance nurse needs to know: a content analysis of curricula in the specialist nursing programme in prehospital emergency care. Int Emerg Nurs. 2015;23(2):127-32. http://dx.doi.org/10.1016/j. ienj.2014.09.002 www.ncbi.nlm.nih.gov/pubmed/25304861

11- Kallestedt ML, Berglund A, Herlitz J, Leppert J, Enlund M. The 
impact of CPR and AED training on healthcare professionals' selfperceived attitudes to performing resuscitation. Scand J Trauma Resusc Emerg Med. 2012;20:26. http://dx.doi.org/10.1186/17577241-20-26 www.ncbi.nlm.nih.gov/pubmed/22480164

12- Seyed Bagheri SH, Rayyani M, Iranmanesh S, Dehghan M, Tirgari B, Hosseini SH. Growth: A Journey from Experience to Higher Perception Among Iranian Muslim CPR Survivors. J Relig Health. 2020;59(2):1024-34. http://dx.doi.org/10.1007/s10943-018-06142 www.ncbi.nlm.nih.gov/pubmed/29679187
13- Alimohammadi N, Baghersad Z, Marofi M. Compression two methods "role playing and video type" of CPR education on knowledge and skills of high school students. J Nursing Educat. 2017;6(3):24-30. http://dx.doi.org/10.21859/jne-06034

14- Govender K, Sliwa K, Wallis L, Pillay Y. Comparison of two training programmes on paramedic-delivered CPR performance. Emerg Med J. 2016;33(5):351-6. http://dx.doi. org/10.1136/emermed-2014-204404 www.ncbi.nlm.nih.gov/ pubmed/26698362 